\title{
Pelatihan Penyusunan Perangkat Pembelajaran Anak Usia Dini Bagi Guru-Guru Paguyuban POS PAUD di Wilayah Tlogomas
}

\author{
Yulianti, Prihatin Sulistyo \\ Universitas Kanjuruhan Malang, yulianti@unikama.ac.id, prihatinsulistyo@unikama.ac.d
}

\begin{abstract}
Based on the results of monitoring of learning at Post PAUD in Tlogomas region in the 20172018 semester, there are several findings in the development of non-formal education institutions among the following; 1). facilities and learning infrastructure that has not been good, 2). The welfare of teachers is still uncertain, 3). administrative demands from partner institutions, and also 4). different curriculum guide of ECD (Formal) with Post PAUD (non Formal), also related teacher competence. This devotion program helps provide partner problem solving that is; mentoring and training of learning tool preparation, the planning stage begins with visits to several PAUD Post. Implementation of each teacher reviewing learning tools, dilanjudkan accompaniment team as well as training the preparation of personal RPPH preparation, then the results are presented in groups to get input repair and end the evaluation with the team of servants. The results of the teacher program can demonstrate the results of the group's work to make the RPPH hope that the follow-up of this activity will be dilanjudkannya in their respective institutions to improve the quality of learning according to student development.
\end{abstract}

Keywords: learning tools; Pos PAUD teachers

\begin{abstract}
Abstrak
Berdasarkan hasil monitoring pembelajaran di Pos PAUD di wilayah Tlogomas pada semester gasal 20172018, ada beberapa temuan dalam pengembangan lembaga pendidikan non formal diataranya berikut; 1). sarana dan prasarana belajar yang belum baik, 2). Kesejahteraan guru yang masih belum ada kepastian, 3). tuntutan administrasi dari lembagalembaga mitra, dan juga 4). berbedanya panduan kurikulum PAUD (Formal) dengan Pos PAUD (non Formal), juga terkait kompetensi guru. Program pengabdian ini membantu memberikan pemecahan masalah mitra yaitu; pendampingan dan pelatihan penyusunan perangkat pembelajaran, tahapan kegiatan perencanaan diawali dengan kunjungan ke beberapa Pos PAUD. Pelaksanaannya setiap guru menelaah perangkat pembelajarannya, dilanjudkan pendampingan tim pengabdi sekaligus pelatihan penyusunan RPPH secara personal, kemudian hasil pembuatan dipresentasikan secara berkelompok guna mendapat masukan perbaikan dan diakhiri evaluasi dengan tim pengabdi. Hasil program guru bisa mendemonstrasikan hasil kerja kelompok membuat RPPH yang harapannya tindak lanjud kegiatan ini akan dilanjudkannya di lembaga masing-masing guna memperbaiki kualitas pembelajaran sesuai perkembangan siswa.
\end{abstract}


Kata Kunci: perangkat pembelajaran; guru pos PAUD

\section{A. PENDAHULUAN}

Menurut Kementerian Pendidikan dan Kebudayaan Direktorat Jendral PAUD disebutkan:

"Pos PAUD merupakan bentuk
layanan PAUD
penyelenggaraannya
diintegrasikan dengan layanan Bina
Keluarga Balita (BKB) dan/atau
Posyandu bagi anak sejak lahir
sampai dengan usia 4 tahun. Pos
PAUD merupakan salah satu model
PAUD yang dikembangkan melalui
pendekatan holistik-integratif, yang
tidak hanya menekankan aspek
pendidikan semata tetapi mencakup
juga aspek pelayanan gizi, pelayanan
kesehatan, pengasuhan, dan
perlindungan anak (Juknis
Penyelenggaraan Pos PAUD 2013)."

Pendidikan anak usia dini merupakan salah satu bentuk penyelenggaraan pendidikan yang menitikberatkan pada peletakan dasar ke arah pertumbuhan dan perkembangan fisik (koordinasi motorik halus dan kasar), kecerdasan (daya pikir, daya cipta, kecerdasan emosi, kecerdasan spiritual), sosio emosional (sikap dan perilaku serta agama) bahasa dan komunikasi, sesuai dengan keunikan dan tahap-tahap perkembangan yang dilalui oleh anak usia dini.

Target luaran yang dihasilkan dalam kegiatan pengabdian ini selain laporan pengabdian pada masyarakat juga terpublikasikan dijurnal pengabdian ber ISSN.

Berdasarkan observasi pada Juni 2016 sampai November 2017 Pos PAUD yang diselenggarakan kelurahan Tlogomas adalah jenis layanan Pendidikan Anak Usia Dini (PAUD) yang berdiri di bawah naungan kebijakan Kepala Kelurahan Tlogomas yang dikembangkan dan dimonitoring pertanggung jawabannya oleh ketua RW.

Di wilayah ini ada $9 \mathrm{RW}$ dan tidak semua RW mendirikan pelayanan Pos PAUD. Ada enam lembaga Pos PAUD diantaranya RW 1 Pos PAUD Seruni, RW 2 Pos PAUD Melati, RW 3 Pos PAUD Sri Rejeki, RW 6 Pos PAUD Mawar, RW.07 PP. Nusa Indah I dan RW.05 Pos PAUD Anggrek.

Pos PAUD di wilayah kelurahan Tlogomas ini berdiri sejak tahun 2008 yang disosialisasikan dan pengkondisian pendirian melalui PKK Pokja II kelurahan yaitu pemberdayaan di bidang pendidikan. Dalam hal monitoring dan pembinaan lembaga Pos PAUD kelurahan ini membentuk struktur organisasi pengelola Pos PAUD yaitu para ketua RW setempat. Penanggung jawab dalam pelaksanaan lembaga pendidikan non formal selain ketua RW di wilayah tersebut juga dibantu pihak kelurahan dibawah naungan ketua pokja II PKK Kelurahan Tlogomas.

Ada dua tujuan diselenggarakannya Pos PAUD di wilayah ini yaitu: Tujuan utama: untuk memberikan pelayanan utama pendidikan pada warga setempat, dengan harapan yaitu anak dapat tumbuh dan berkembang sesuai dengan tingkat perkembangannya sehingga memiliki kesiapan yang optimal di dalam memasuki pendidikan dasar serta mengarungi kehidupan di masa dewasa. Tujuan penyerta: untuk membantu menyiapkan anak mencapai kesiapan belajar (akademik) di sekolah.

Berdasarkan analisis situasi dan kondisi di lapangan yang menjadi latar belakang program pengabdian ini karena ada beberapa kendala yang jadi masalah mitra diantaranya: 
1). sarana dan prasarana belajar yang belum baik, 2). Kesejahteraan guru yang masih belum ada kepastian, 3). Tuntutan administrasi dari lembaga-lembaga mitra, dan juga 4). Kesenjangan panduan kurikulum PAUD (Formal) dengan Pos PAUD (non Formal), juga terkait kompetensi guru dalam memberikan pelayanan pendidikan sesuai perkembangan usia peserta didik.

Berdasarkan Permendikbud Nomor 146 Tahun 2014 Tentang Kurikulum 2013 PAUD, Dokumen KTSP terdiri dari :

"Dokumen 1 berisi sekurangkurangnya: visi, misi, tujuan satuan pendidikan, program pengembangan dan materi pembelajaran, pengaturan beban belajar, kalender pendidikan dan program tahunan, dan SOP. Dokumen 2 berisi perencanaan program semester (Prosem), rencana pelaksanaan pembelajaran mingguan (RPPM), dan rencana pelaksanaan pembelajaran harian (RPPH) yang dilengkapi dengan rencana penilaian perkembangan anak."

Berkaitan dengan tugas guru sebagai perencana, perencanaan pembelajaran wajib disusun oleh guru secara mandiri. Terdapat tiga jenis perencanaan pembelajaran yang harus disusun dan disiapkan oleh guru sebelum melaksanakan pembelajaran yaitu:

1. Program Semester (Prosem)

2. Rencana Pelaksanaan Pembelajaran Mingguan (RPPM)

3. Rencana Pelaksanaan Pembelajaran Harian (RPPH)

Solusi yang ditawarkan untuk membantu menyelesaikan permasalahan tersebut adalah adanya pertemuan pelatihan dan pendampingan pada guruguru Pos PAUD Se-Tlogomas. Programprogram tersebut diharapkan akan membantu mengarahkan para guru dan pengelola dalam penyamaan persepsi penyusunan perangkat pembelajaran Pos PAUD. Setelah para guru berkumpul menyamakan persepsi penyusunan perangkat pembelajaran yaitu PROTA, PROMES, RPPH dan RPPM maka guru akan mudah menyusun bahan persiapan sebelum mengajar. Target luaran dari kegiatan pengabdian ini terbentuknya kegiatan-kegiatan paguyuban Pos PAUD Tlogomas untuk merancang format rencana pelaksanaan pembelajaran sesuai dengan wilayah Tlogomas.

\section{B. PELAKSANAAN DAN METODE}

Secara umum pelaksanaan pengabdian ini dilakukan dengan tahapan sebagai berikut:

1. Pelatihan dengan metode diskusi/ sherring ; Pelatihan Menyusun program semester (Promes)

Langkah-Langkah Penyusunan Program Semester; Penyusunan program semester dilakukan dengan langkah berikut. 1). Membuat daftar tema satu semester. Pemilihan dan penentuan, 2). tema dilakukan guru sebelum awal semester kegiatan pembelajaran, 3). dimulai dengan memperhatikan prinsip pengembangan tema, 4). Mengembangkan tema menjadi subtema dan atau sub-subtema, 5). Subtema dan sub-subtema yang dikembangkan merupakan, 6). topik-topik yang lebih khusus dan lebih dalam. Kekhususan, 7). dan kedalaman subtema dan sub-subtema memperhatikan, 8). usia anak, kesiapan guru, dan ketersediaan sumber belajar, 9). pendukung. Pengembangan tema dapat dipelajari pada PedomaN, 10). Pengembangan Tema, 11). Menentukan alokasi waktu untuk setiap tema, subtema atau sub-subtema, 12).Waktu pembahasan setiap tema/subtema/subsubtema disesuaikan 
dengan minat anak, keluasan, kedalaman, dan sumber/media yang tersedia. Menetapkan Kompetensi Dasar (KD) di setiap tema. Penentuan KD memuat seluruh aspek perkembangan Nilai Agama dan Moral (NAM), fisik-motorik, kognitif, sosial-emosional (sosem), bahasa, dan seni.KD dapat ditulis lengkap atau dapat dituliskan kodenya saja. KD dapat diulangulang di tiap tema/subtema/sub-subtema yang berbeda.

2. Workshop; pembagian kelompok Tiap kelompok membuat rencana pembelajaran yang dibagi ada kelompok RPPM dan kelompok RPPH dan Rencana Pelaksanaan Pembelajaran Mingguan (RPPM) disusun untuk pembelajaran selama satu minggu. RPPM dijabarkan dari Program Semester. RPPM berisi: (1) identitas program layanan, (2) KD yang dipilih, (3) materi pembelajaran, dan (4) rencana kegiatan.

3. Identitas Program Layanan memuat sebagai berikut:

a) Nama Satuan PAUD adalah nama satuan PAUD yang

b) Semester /bulan/minggu yang keberapa

c) Tema/Subtema/Sub-subtema diambil dari tema/subtema/

d) sub-subtema yang disusun di program semester.

e) Kelompok usia anak diisi dengan kelompok sasaran program

4. Melanjudkan pendampingan menyusun RPPH

Rencana pelaksanaan pembelajaran harian (RPPH) merupakan acuan untuk mengelola kegiatan bermain dalam satu hari. RPPH disusun dan dilaksanakan oleh guru. Format RPPH tidak harus baku, tetapi memuat komponen-komponen yang ditetapkan. Komponen RPPH terdiri atas: (1) identitas program, (2) materi, (3) alat dan bahan, (4) kegiatan pembukaan, (5) kegiatan inti, (6) kegiatan penutup, dan (7) rencana penilaian.

Identitas sebuah RPPH memuat: nama Satuan PAUD adalah nama satuan PAUD yang menyusun RPPH, semester/bulan/minggu yang keberapa, hari/tanggal, tema/Subtema/Sub-subtema diambil dari tema/subtema/sub-subtema yang disusun di program semester, kelompok usia anak diisi dengan kelompok sasaran.

Implementasi rencana pelaksanaan pada pembelajaran Pos PAUD, Refleksi dan Tindak lanjud kegiatan ini merupakan refleksi dari implementasi penyusunan perangkat pembelajaran, semua catatancatatan perbaikan akan didiskusikan bersama sehingga bisa jadi rujukan untuk perbaikan dalam penyusunan dan saat pembelajaran.

\section{HASIL DAN PEMBAHASAN}

1. Workshop dan pelatihan menyusun program semester (Promes), RPPM dan RPPH

Pelaksanaan workshop dan pelatihan bertempat di balai RW 03 Pos PAUD Sri Rejeki RW 03 yang diikuti oleh perwakilan guru-guru dari sekolah-sekolah mitra. kegiatan ini dilakukan 2 jam secara berkelompok yang didampingi tim pengabdi 2 dosen PGSD Universitas Kanjuruhan Malang dan 1 mahasiswa karena yang lain berhalangan. Kegiatan ini dilakukan dengan tujuan untuk memberikan wawasan dan penyegaran para guru Pos PAUD dalam menyikapi siswa usia dini. Pemahaman penyusunan perangkat pembelajaran harus bisa dikuasai oleh setiap guru guna memperbaiki kualitas pembelajaran. Hal ini mengingat kondisi di lapangan jumlah siswa tiap Pos PAUD yang banyak dan bervariasi, maka harus disikapi seorang guru yang selain bisa menguasi kelas juga matang persiapannya. Kegiatan pelatihan 
ini diberikan pada guru-guru Pos PAUD untuk memberikan kontribusi baik buat masing-masing lembaga dimana guru ditugaskan.

Bagi para guru atau kepala sekolah yang mewakili, melalui kegiatan pelatihan ini harapan bisa memiliki pemahaman dan kompetensi dalam mengajar. Kepala sekolah dan pihak pengelola Pos PAUD Tlogomas juga diharapkan bisa sebagai fasilitator dan motivator sehingga guruguru memahami danmengimplementasikan dalam persiapan hingga proses pembelajarannya.

Kegiatan ini dilakukan oleh 2 tim dosen Universitas Kanjuruhan Malang, bu Prihatin Sulistiyawati menyampaikan prolog materi perangkat pembelajaran dan materi kedua bu Yulianti menyampaikan materi Promes, RPPM dan RPPH dilanjudkan sesi tanya jawab mengenai kesulitan dan semua kendala dalam menyelesaikan penyusunan RPPH selesai.

Berdasarkan hasil workshop yang sudah dilakukan tim pengabdi ada beberapa manfaat yang dirasakan oleh para guru Pos PAUD; 1). guru memiliki pemahaman konsep perangkat pembelajaran prota, promes, RPPM, dan RPPH yang sebelumnya tidak memahami karena tidak kenal dan menjadi guru karena ditunjuk pak RW. 2). keterampilan guru bertambah baik dalam menyusun atau membuat rencana mengajar, 3). kemantapan guru dalam mengimplementasikan rencana mengajar yang dibuat untuk kualitas pembelajaran.

2. Pendampingan dan Implementasi Rencana Pelaksanaan Pada Pembelajaran Pos PAUD

Kegiatan selanjudnya setelah workshop dan pelatihan yaitu adanya pendampingan dalam proses pembuatan sampai pada implementasi, ini dilakukan oleh tim pengabdi secara bertahap. Pada bulan
September, Minggu pertama Pos PAUD/ PP. Sri Rejeki, PP. Melati, Kedua; PP. Seruni, PP. Mawar dan PP. Anggrek.

\section{a. Pendampingan Pertama}

Kegiatan ini dilakukan pada hari Sabtu Minggu pertama. Pelaksanaan pendampingan berfokus pada menyusun RPPH. Adapun hasil kemajuan dari peserta pendampingan sebagai berikut;

Guru PP. Sri Rejeki dan PP. Melati

Bahan yang dirancang mengikuti struktur kurikulum 2013; muatan kurikulum Pos PAUD berisi program-program pengembangan; nilai agama dan moral (nam), fisik motorik, kognitif, bahasa, sosial emosional dan seni, yang dirangkum dalam kompetensi inti yaitu gambaran pencapaian standart tingkat pencapaian perkembangan anak pada akhir layanan, yang disebut kompetensi dasar sikap spiritual (KI-1), kompetensi dasar sikap sosial (KI-2), kompetensi dasar pengetahuan (KI-3), kompetensi dasar keterampilan (KI-4). Berikut gambaran penyusunan Prota dan Promes untuk pelaksanaan semester ganjil 2017/2018

Tema Binatang, macam-macam binatang peliharaan, cara merawat dan jenis makanan.

\section{Kompetensi Dasar:}

1.1, 1.2, 3.1-4.1 (Nam),

2.1, 3.3-4.3, 3.4-4.4 (Motorik)

2.9, 2.10, 2.11, 2.12, 3.13- 4.13 (Sosem),

$2.3, \quad 3.5-4.5, \quad 3.6-4.6, \quad 3.7-4.7,3.9-4.9$ (Kognitif),

2.14, 3,10-4.10, 3.11-4.11 3.12, 4.12

(Bahasa), 3.15- 4.15 (Seni)

sub tema dan alokasi waktu

Ayam 1 minggu, Ikan 2 minggu, Kupukupu 3 minggu, Belalang 1 minggu, dan Harimau 1 minggu

berdasarkan kompetensi tersebut; guru merancang tema binatang dengan sub-tema nama-nama binatang kemudian guru 
memahami setiap bunyi KD (kompetensi Dasar) untuk menjabarkan sesuai Standar Tingkat Pencapaian Perkembangan Anak (STPPA) yang akan dikembangkan dan dilanjudkan dengan menjabarkan indikator-indikatornya.

\section{b. Pendampingan Kedua}

Tahap kedua dilakukan pada Minggu kedua Bulan September 2017. tim pengabdi selain bertatap muka dengan mitra juga memberikan buku petunjuk teknis dalam menyusun perangkat pembelajaran sebagai pemandu para guru dalam membuat rencana pembelajaran. Adapun hasil kemajuan peserta pendampingan sebagai berikut;

PP. Seruni, PP. Mawar dan PP. Anggrek

proses pendampingan dilakukan secara kelompok dengan model FGD (focus group discusion) dari masing-masing peserta saling memberikan umpan balik untuk perbaikan dari bahan yang dipresentasikan oleh tiap-tiap kelompok.

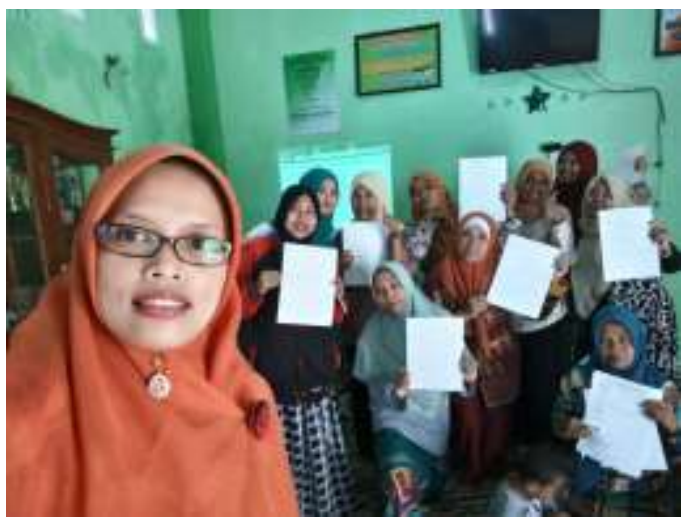

Gambar 1. Hasil pembuatan RKKH

Gambar di atas menunjukkan hasil karya yang telah diimplementasikan peserta pendampingan selesai kegiatan merancang persiapan mengajar.

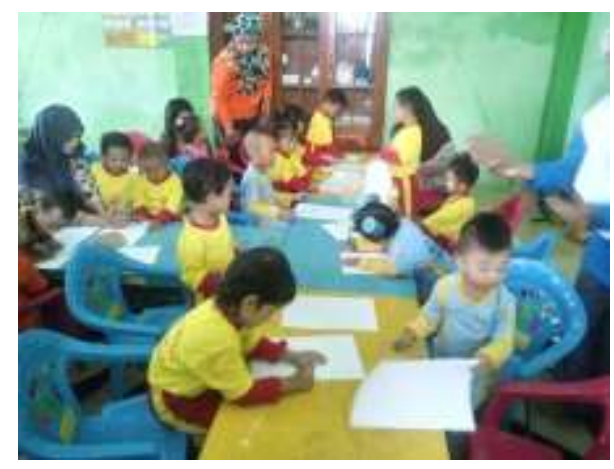

Gambar 2. Implementasi Dalam Pembelajaran

Setelah peserta mendapat pemahaman dan keterampilan menyusun dan mengembangkan diwujudkan dengan aktualisasi perserta dalam pembelajannya. tentunya disesuaikan Standar Tingkat Pencapaian Perkembangan Anak merupakan kriteria minimal tentang kualifi kasi perkembangan anak yang mencakup aspek nilai agama dan moral, fisik motorik, kognitif, bahasa,sosial-emosional, dan seni.

\section{PENUTUP}

\section{Simpulan}

Berdasarkan hasil pelatihan dan pendampingan yang sudah tim pengabdi lakukan maka dapat disimpulkan sebagai berikut:

1. Workshop dan pelatihan penyusunan perangkat pembelajaran dirancang mengikuti prinsip-prinsip pembelajaran, keluasan muatan/materi, pengalaman belajar, tempat dan waktu belajar, alat/sumber belajar, model pembelajaran dan cara penilaian.

2. Prota, Promes, Prota, RPPM dan RPPH disusun dan dikembangkan sesuai karakteristik siswa di wilayah setempat.

\section{Saran}


Saran dari pelaksanaan pengabdian ini bagi para pendidik atau guru Pos PAUD dalam proses pembelajaran untuk menyiapkan persiapan pembelajaran. dan tim pengawas dari instansi kelurahan sebaiknya membantu pelaksanaan kegiatan paguyuban Pos PAUD guna menjembatani perselisihan antar lembaga Pos PAUD se Tlogomas.

\section{E. DAFTAR PUSTAKA}

Direktorat Pendidikan Anak Usia Dini, Kementerian Pendidikan Dan Kebudayaan Tahun 2015. Buku Panduan Penyusunan Rencana Pembelajaran Bagi Anak Usia Dini,.

Direktorat jenderal pendidikan anak usia dini, Nonformal dan informal. Direktorat pembinaan pendidikan anak usia dini 2013. Petunjuk teknis Penyelenggaraan Pos Paud Kementerian pendidikan dan kebudayaan.

Kerangka Dasar dan Struktur Kurikulum 2013 Pendidikan Anak Usia Dini. Kementerian Pendidikan dan Kebudayaan Direktorat Jendral PAUD dan Pendidikan Masyarakat Direktorat Pembinaan PAUD Tahun 2013

\footnotetext{
Pengelolaan Pembelajaran PAUD.

Kementerian Pendidikan dan Kebudayaan Direktorat Jendral PAUD dan Pendidikan Masyarakat Direktorat Pembinaan PAUD Tahun 2013.
}

Pengembangan Tema Pembelajaran PAUD. Kementerian Pendidikan dan Kebudayaan Direktorat Jendral PAUD dan Pendidikan Masyarakat Direktorat Pembinaan PAUD Tahun 2013.

Hendarwati, Endah. dkk. Pelatihan Pembelajaran Inovatif, Penyusunan Perangkat Pembelajaran dan Pembukuan Pada Bunda PAUD. Aksiologiya: Jurnal Pengabdian Kepada Masyarakat, Vol.1, No.2, Agustus 2017, Hal.81-91, ISSN 2528-4967 (Print) dan ISSN 2548291X (online) http://journal.umsurabaya.ac.id/ 